\title{
MOZAIKOK A REGIONÁLIS IDENTITÁS ÉRTELMEZÉSÉHEZ ${ }^{1}$
}

\author{
(Aspects of the Interpretation of the Regional Identity)
}

\section{SOMLYÓDYNÉ PFEIL EDIT}

\begin{abstract}
Kulcsszavak:
regionális identitás régiófogalom régióközpont részvételi demokrácia kommunikáció

Milyen ùt vezet a regionális identitás kialakulásához? Milyen szerepe van ebben a térnek és a kultúrának, illetve beszélhetünk-e a regionális identitás sajátos jegyeiröl? A regionális identitás fogalma meglehetősen uj keletü, mint magának a régió regionalizálásának koncepciója is, azonban a térabsztrakció emocionálissá válásához hasonló tényezókre van szükség, mint az identifikáció más formái esetében. Legfóképpen a részvételi demokrácia eszközeinek és a kommunikáció jelentöségének felfedezése jelentheti a kulcsát az új térstruktúrák bevezetésének, miközben nem tagadható a regionális intézményesités szerepe sem.
\end{abstract}

\section{A regionális identitás bölcsöje}

A regionális identitás relatíve új fogalmat takar, mely a területi vagy területhez kötődö identitás egyik válfaja. Megszületése a regionális fejlödés politikai koncepciójảhoz kapcsolódik, amely decentralizációs koncepcióként is felfogható. A regionális identitás fogalma még közel sem kidolgozott, ami nem kevéssé azzal a ténnyel függ össze, hogy a regionális politika regionalizálásának jelszava sem olyan régi keletú, Nyugat-Európában a késó 1970-es években született meg. A folyamat abból fakadt, hogy a területi különbségek csökkentésében, az elmaradott térségek felzárkóztatásában az addigi politika cezúrához érkezett, erőforrásai kimerültek. Az új szlogen szerint a centralizált állami politikát fel kell váltania az endogén, régióspecifikus potenciálokra építỏ és a regionális sajátosságok kiaknázása révén nemzetközi versenyelőnyhỏz jutó regionális politikával. Az üdvözlendő új stratégia mindjárt bele is ütközött több problémába, elsőként abba, hogyan közvetíthetők a különféle területi szintek, másodszor pedig gyenge volt az a politikai adminisztratív infrastruktúra, amelynek az új politikai irányvonalat hordoznia kellett volna, különösképpen, ami az állampolgári legitimációt illette. Az ellenkező oldalról viszont a regionalizmus új koncepcióját erősítette, hogy mind egyértelmübbé vált, miszerint a gazdasági folyamatok kistérségi, illetve lokális szinten kellỏ mértékben nem befolyásolhatók, szükség van a regionális léptékre. Ennek megfelelően a regionális fejlesztési politika hordozói maguk a régiók, míg a regionális politika állami politika, mely utóbbinak szervesen együtt kell múködnie az előbbivel. A regionális fejlesztési politika olyan jövőképet eredményez, mely regionális fejlesztési koncepciókban, programokban ölt testet, amelyek a területi-helyi akaratképzés eredményeként születnek meg, nem kevéssé a helyi források bevonásának célzatával (Kruse 1990). 
Általában feltételezik, ha a régiók valamilyen mértékủ tervezési vagy politikai önállóságot élveznek, akkor a régió lakosságának, de legalább politikai elitjének kifejlőđik egy bizonyos mértékủ regionális öntudata, majd esetleg regionális identitása. A decentralizált területpolitika döntési mechanizmusa látszólag kedvező táptalaját biztosítja az identitásformálásnak, hiszen a regionalizációban megtestesülö politikai konszenzus létrehozása feltételezné, illetve igényelné a lakossági elfogadottságot, azonosulást. A feltételes módnak azért van itt helye, mert ez bizonyos országokban mủködik, másutt viszont nem. Nálunk csak a kezdeti formális lépéseknél tart, gondolunk itt a törvényhozó által a régió, a megye és a kistérség szintjén 2004-ben berendezett civil egyeztető fórumok múködésének hol kisebb, hol nagyobb mértékủ formalizmusára. Illetőleg arra, hogy számos megyében és kistérségben teljességgel hiányzik az intézmény, noha kötelezỏ lenne létrehozása.

$\mathrm{Az}$ mindenesetre igaz, hogy az Unió egyes dokumentumai tartalmazzák azt az ajánlást (Soós 2001), hogy az állam által felülről kezdeményezett, tradíciókkal nem renđelkező regionalizációról - legalább az intézményesítés végső fázisában - célszerủ a lakosság bevonásával, referendummal dönteni. Ehhez képest a közigazgatás regionális átszervezése tárgyában a magyar Parlament 2006-ban két esetben hozott döntést anélkül, hogy kíváncsi lett volna a választópolgárok véleményére, esetleg felmérte volna a nagy horderejủ döntés társadalmi-gazdasági stb. hatásait. A regionális önkormányzat bevezetéséről és egyidejủleg az ezer éves megye eltörléséről szóló törvényjavaslat-csomagot szinte puccsszerúen tárgyalta a T. Ház. A szabályozási koncepció előkészítéséről és tartalmáról még a szakmai közvélemény sem értesülhetett, az kizárólag pártpolitikai színtéren formálódott. A kétharmados törvénycsomag bukását végül az ellenzékkel elmulasztott egyeztetés okozta. A kormányzópárt egy valamiről bizonyosan elfeledkezett, hogy egy ilyen volumenủ reformot az állampolgárok bevonása nélkül nem lehet sikerre vinni. Vagyis az sem elegendő, ha a döntést végsö stádiumában bocsátják népszavazásra, mert talán még annál is fontosabb lenne az a folyamatos kommunikáció, amely a régióépítés folyamatát erősítené. Ez az egyébként sok időt és költséget felemésztő procedúra hathatósan elő tudja segíteni a régióval, mint új élettérrel történő azonosulást, sőt, a soha megelőzően nem létezett regionális identitás csírájának elültetésére is alkalmas tényező lehet. Ugyanis nem attól várható a regionális reform társadalmi elfogadottsága, hogy a Magyar Közlönyben kihirdetik a regionális önkormányzatot intézményesítö törvényeket, hanem az emberekkel folytatott párbeszédtől.

Visszakanyarodva tehát a területi politikához, annak célja, hogy a strukturális különbségeket a régiók között és a régiókon belül kiegyenlítse. Más országokban ez még jellemzően kiegészül egy lényeges jeggyel, tudniillik a kulturális identitás támogatásával. Látszólag a két cél - a kiegyenlítés, másrészt a sokszínủség támogatása - között ellentmondás feszül. Valójában azok a sikeres és optimális intézkedések, amelyek egyidejủleg szolgálják a két preferenciát, mivel azok erősítỏen hatnak egymásra: egyfelől a nemkívánatos területi különbségek leépítése eredményesebb, ha a régiók kulturális sokszínűsége és autonómiája kibontakozik, mivel fenntartható fejlődési pályára állásuknak ez az egyik záloga. Noha azt szokták mondani, hogy a 
régió a gazdaság átstrukturálódásának, hálózatosodásának terméke, mégsem elegendő a régiót, mint gazdasági teret értelmeznünk, a társadalom strukturális tagozódása, a hatalom-szervezés és a kulturális szimbólumok stb. szempontjából is figyelembe kell vennünk.

Ezzel összefüggésben érdemes pozitívumként kiemelni, hogy 1996-ban, amikor a területfejlesztésröl és területrendezésről szóló törvényt sikerült eukonform módon megalkotni, már belekerült a területfejlesztési célok és feladatok sorába ,a nemzeti és térségi identitástudat megtartása és erősítése" [Tft. 2. § bekezdés d) pont]. Azonban nem sok kétség fér hozzá, hogy ennek megvalósítására egyáltalán nem összpontosult figyelem az elmúlt tíz esztendőben. Hazánkban a regionális politika leginkább különféle intézmények szabályozásában és pénzügyi támogatások elosztásában nyilvánul meg. A területi tervezés szerepe pedig, amely tág teret tudna nyitni a társadalmi csoportok, civilek és gazdasági szereplök számára a regionális fejlesztési politikában való részvételre, pusztán formális jelentőségüvé degradálódott.

\section{A régiófogalom és az identitás lehetséges kapcsolata}

A regionális identitás kutatásában egy egész sor tudományág érdekelt, mintegy multidiszciplináris megközelítésben: a földrajz, a szociológia, a néprajz, a filozófia és a politológia egyaránt. Valamennyi igyekezett hozzájárulni a fogalom definiálásához, amely vizsgálata fénykorát az 1980-as évek derekán élte. Miután a régió maga is sokféleképpen értelmezödő, fejlödésben lévö fogalom, úgy véljük, hogy az identitás gyökereit a régió mibenlétében kell keresni, egyszerúen elválaszthatatlan a régió meghatározásának jellemzőitől. A fogalmi megközelítések különbséget szoktak tenni deskriptív és normatív régiófogalom között, azonban mindkettő esetében lényeges, hogy a régió, amelyhez való kötődés létrejön, az egység és a különbözőség sajátos feszültségében helyezkedik el. Az egyén és a közösség, mint az identitás alanya tudatosan vagy öntudatlan keresi azokat az elemeket, struktúrákat vagy funkciókat, amelyek egységbe vonják az adott régiót és elválasztják egy másiktól. A kulturális, a gazdasági vagy az ökológiai régió általában deskriptivnek tekinthetö, míg a területfejlesztési-tervezési régió és a programrégió, de még inkább a közigazgatási régió feltétlenül normatív jellegủ. Az előbbiek rendszerint nem is igénylik a merev földrajzi lehatárolást, illetve az gyakran nehézségekbe is ütközne. A gazdasági régió területi léptéke meghatározható, azonban határai dinamikusan alakulnak, és időben változhatnak (Wiechmann 2000).

Nyilvánvaló törekvés tapasztalható a komplex régiófogalom megragadására, mely túllép az aprólékos differenciáláson és szintetizálni igyekszik az összetartozó jegyeket, elötérbe helyezi az adott téregységnek a központi államhoz mért függetlenségét, a régió fejlesztéséért viselt közös felelősséget, a hálózati együttmüködéseket, kapcsolatokat. A normatív régió létrehozása tehát nem szükségképpen az elsỏ lépés a regionalizáció útján, mindenesetre segíthet a régióra vonatkozó kognitív és emocionális információk és tudások létrejöttében. A területfejlesztési és/vagy közigaz- 
gatási régió valóságos, kézzelfogható megvalósulását nehezíti, hogy térbeli egységének, határainak megragadása feltételezné az emberek és szervezetek mozgáspályáinak átalakulását, sőt egyenesen kitágulását. Tapasztalható, a régió mint intézmény egyetlen politikai döntéssel létrehozható, de hogy müködőképes lesz-e, az sokkal összetettebb probléma. Így nálunk a megyehatárokat átszelő regionális kohézió létrejötte a régiót behálózó új társadalmi-gazdasági-kulturális stb. kapcsolatok kiépülését feltételezné, arra lenne alapozható. Ez a gazdasági szereplők részéről úgy-ahogy abszolválható, de egyáltalán nem irányítható, és nagyban fưgg a helyi gazdaság erősségétől, sőt versenyképességétől is. Az egyének és civil szervezetek beágyazódása az új, nagyobb léptékủ térbe anyagi, egzisztenciális lehetöségek függvénye is, külső-belső infrastrukturális, közlekedési feltételeknek erősen kitett, lassan építkező folyamat. Valószínüsíthetö, hogy a deskriptív régió lakosai könynyebben megtalálják az identifikációjukhoz szükséges tényezőket, hiszen kutatások bizonyítják (Oláh 2000), hogy a területi kötödés kialakulásában például a jövedelemszerző képességnek lényeges szerepe van.

A regionális öntudat olyan ismereteket jelent az adott területi egység regionális sajátosságairól, melyek meghatározzák az egyedi életteret és a tudást az ott éló emberekröl. Viszont ez az öntudat még egyáltalán nem azonosítható azzal az emocionális kötödéssel, amely mint regionális identitás az embereket a régióhoz köti -állítják más szerzők (Blotevogel-Heinritz-Popp 1987). Így a regionális identitás kifejlődése nem történik egy csapásra, sőt a területi kötödésnek fokozatai különíthetök el: a regionális öntudat, a regionális identifikáció, majd a valahova tartozni akarás vágya. $\mathrm{S}$ a területi kötődéssel párhuzamba szokták állítani a regionalizmus érési fokozatait, úgy mint

- diffúz regionalizmus - egy szimbolikus helyre vonatkoztatott kötődést testesít meg;

- tudatos regionalizmus - benne kifejezésre jut az egyéneknek, közösségeknek egy helyre vonatkoztatott hovatartozás-érzése, olyannyira, hogy a régióhoz való kötődés aktív akadályát képezi az elvándorlásnak;

- artikulált regionalizmus - a regionális diszparitásokból és a kulturális sajátosságokból építkező jellegzetes öntudat, amelyböl az érintett régióra vonatkozó kollektív értékek és érdekek artikulálódnak;

- gyakorolt regionalizmus - a regionalizmusnak ezen a minőségi fokán a regionalizmus a politikai és kulturális cselekvés vonatkoztatási keretévé alakul, például az adott régió politikai és kulturális autonómiájáért vívott harcban (Meier-Dallach 1980).

Vannak olyan szerzök, akik kétségbe vonják a regionális identitás fokozatokba sorolhatóságát, de leginkább azt, hogy a regionális identitás intenzitása emocionális kötödések függvénye lenne. Ezt azzal magyarázzák, hogy a fejlett modern társadalmak egyik fontos ismérvévé vált a tértöl való függetlenedés, mivel a tömeges migráció lezajlása révén egész embercsoportok hagyják el tradicionális helyeiket, $\mathrm{s}$ kezdik csoportjuk történelmét egy más helyen újradefiniálni (Szijártó 2002). Véle- 
kedésünk szerint a területi kötődés mindenképpen az adott térkategória megéléséből, szocializációs mintákból, a társadalmi-gazdasági helyzetből, a kulturális tradíciókból, a társadalmi interakciókból és sok másból építkezik. Így a kultúrának és a térnek továbbra is meghatározó a jelentősége. Már csak azért is, mert a mindennapi élet kommunikációs stratégiáinak vizsgálatakor (Szijártó 2002) fény derül arra, hogy az identitás felépitésében egy adott földrajzi hellyel, valamilyen vidékkel, vagy távolabbi régióval való azonosulásnak továbbra is meghatározó szerepe van. Ezeket az adott csoport számára központi jelentöségü helyeket tekinti a kulturális antropológia olyan strukturált belső tereknek, amelyeken belül sokkal intenzívebbek az interakciók, sủrübb a mindennapokat konstituáló kommunikációs háló, hatékony jelentés- és szimbólumtermelés folyik. S mindezen tényezők elkülönítik, kiemelik a teret más külsó, az identitás termelése szempontjából nem releváns terektől.

\section{Régióhatár vagy régióközpont?}

Mindezek alapján a korábbi kutatások a regionális identitás fejlődésének három komponensét különböztetik meg:

1) A régióhatárok megvalósulását, realizálódását.

2) Az identifikációt, az egyén önbesorolását.

3) A regionális hatású cselekvés perspektíváját.

Tehát a regionális identitás elvileg egy stabil, generális kognitív struktúra.

Az első komponens tekintetében a nehézség abban mutatkozik meg, hogy az objektív régióhatárok, amelyek történelmileg, tradicionálisan kialakultak, vagy amelyeket éppen kívülről, felülről állapítottak meg (hazánk esetében a jogalkotás húzta meg őket), vajon egybeesnek-e a szubjektív régióhatárokkal, vagyis a regionális, illetve a területi identitással? Úgy tünik, azzal a kérdéssel meglehetősen csínján kell bánni, hogy vajon létezik-e regionális identitás Magyarországon, hiszen a szerves fejlődés alapjai hiányoznak hozzá (Szörényiné Kukorelli 2000). De vajon az egyének, a társadalmi csoportok azonosulni tudnak-e a megvont régióhatárokkal? Vagy megforditható-e a kérdés, hogy a népesség érdekek, értékek, identitások szerinti tagolódásában mutatkoznak-e cezúrák és területi különbségek? A regionális identitás területi léptéke megragadható-e?

A regionális identitás vezérszava, a területhez kötöttség meglehetősen erős magatartásmintát takar, de amelynek nem feltétlenül, illetve nem kizárólagosan a területi határokat kell jelentenie. Miután a regionális öntudat egyáltalán nem individuális jelenség, a benne megnyilvánuló téregység az emberek és intézmények közötti kapcsolatok révén épül fel. Kollektív jellege abban is megnyilvánul, hogy általában valamilyen nevet visel, melyhez való viszonyulás megalapozza a regionális öntudat kialakulását. Kétségbe vonhatatlan, hogy a téregység elnevezése, nevének egyedisége a hozzá kötődők számára nagy jelentőséggel bír. Érdemes kiemelni, hogy az a terület, amit például régiónak tekintenek, elnevezését gyakran annak centrumáról, 
központi helyzetü településéről, városáról kapja, legalábbis a nyugat-európai minták ezt bizonyítják. A centrumváros maga, mint polgárosult hely általában történelmi és kulturális gyökereket elevenít fel, ami pozitív módon kihat az identitásra. Az individuális és a kollektív szint között az öntudat erősítése szempontjából mindenképpen kölcsönhatás figyelhetỏ meg. Sőt, az idevonatkozó vizsgálatok szerint minél erőteljesebben ivódik bele a téregység neve az emberek tudatába, annál világosabban artikulálódik a kollektív területi kötödés (Blotevogel-Heinritz-Popp 1987). Innen nézve, ha a régió, különösen a gazdasági régió külső határai nem is relevánsak, a vonzásközpontja szilárd bázisát, vonatkoztatási pontjảt adhatja a régió létének.

Itt érdemes megállni egy pillanatra, hiszen Magyarországon a területi kötődésnek új potenciális bázisai jöttek létre a területfejlesztés intézményrendszerének megalapításával. A régió normatív jellege 1999-ben érzékelhetővé és egyértelművé vált a területfejlesztési régiók határainak megvonásával. Ami az új területi egységek elnevezését illeti, azzal már több baj van. A mesterségesen, a megyék mechanikus öszszekapcsolásával létrehozott régiók területi kapcsolatok és belső összetartozás hiányában kevesekben ébresztettek érzelmeket. Egy évtizede nem tudott megszületni a konszenzus abban, hogy mely városok legyenek a régióközpontok. Egyébiránt a szakmai álláspont szerint a városnak van régiója, $\mathrm{s}$ nem fordítva, a régiónak központja. Legújabban pedig az Európai Unió policentrikus városfejlesztési koncepciójára hivatkozással próbálja a területi politika eliminálni ennek a kérdésnek a súlyát. Az országos hatókörú tervdokumentumokba öntött hivatalos álláspont szerint egyetlen régiócentrum kijelölése helyett a (nagy)városok hálózatos együttmüködése és a regionális állami funkciók megyeszékhelyek közötti megosztása az egyetlen üdvözítő út. Ily módon a területi államigazgatási funkciók és a nekik megfelelö intézmények, szervek utóbbi egy évben tapasztalt elosztása a régiót alkotó megyék székhelyei között mintegy a régiócentrum szükségességének tagadásaként manifesztálódott. Holott általában nemzetközi szinten egyetértés mutatkozik abban, hogy a városhálózat policentrikus szerkezetének fejlesztése a hálózat elemei között fennálló funkcionális hierarchián alapuló kapcsolatok vonatkozásában csak kiegészitő jelleggel érvényesülhet, azt nem helyettesítheti. Ezt támasztják alá azon tapasztalatok (Horváth 2007), miszerint számos országban a régióközpontok és régiójuk kijelölése a nemzeti regionális politika decentralizációs áramába tartozott, nem pedig a centralizációt vagy a koncentrációt kifejező döntések közé. S általános tendenciaként megállapítható, hogy régióközpontokká a régió legnagyobb városai válnak.

$\mathrm{Az}$ 1980-as évek Nyugat-Európájában elvégzett empirikus identitásvizsgálatok olyan eredményre vezettek, hogy a regionális tervezési és implementációs tevékenységben alkalmazott módszerek, mint a központi helyek szerinti tértagolás vagy a hálózatok, továbbá a fejlődési tengelyek kijelölése indukálta hierarchia határozottan a decentralizált koncentráció irányába vitték el a regionalizmust. Ez pedig a területi kötődés erősödését eredményezte a regionális öntudat terén. 
Végsö soron tehát arra a következtetésre juthatunk, hogy a regionális önazonosság kétféleképpen fogható fel:

1) Egy meghatározott területi egységhez való kötödés tudata érthető alatta, ami mindenekelött jelenti a szülőföldhöz való tartozás érzését. Ebben különféle materiális, nyelvi, kulturális stb. szimbólumok kerülnek előtérbe.

2) Másfelöl a regionális identitás jelentheti a mindennapi tudat régióspecifikus kifejezódését, a különféle szocio-kultúrákat, illetőleg a területi problémák és a közös fejlődés kérdésének megragadását. Eszerint, mint a regionális politikai kultúra egy aspektusa vizsgálható.

Ily módon az első megközelítés sokféle faktor, mint a nyelv, a vallás, a média, a történelmi fejlődés, a kulturális szokások stb. összhatásaként határozza meg a regionális önazonosságot. A másik megközelítésben viszont a regionális identitás lényegében a régiók közötti fejlettségbeli különbségekre épül, a szomszédos régiók fejlettségéhez való viszonyban, az összehasonlításban és különbözésben tudják meghatározni magukat a szereplök. Éppen ezért egyik megnyilvánulása kell, hogy legyen a nagyfokú nyitottság és fogékonyság a technikai megújulás és fejlődés irányában, továbbá egy optimista hozzáállás az adott területi egység gazdasági megújulása és felzárkózása iránt. Ebből fakad aztán a projektek iránti elkötelezettség és tenni akarás. Sőt, a vázoltak alapján a regionális identitásnak az is sajátossága, hogy például a régió határainak megvonása nem pusztán egy földrajzi határt testesít meg, hanem a regionális öntudat számára többnyire, mint centrum periféria viszony is értelmezódik. A regionális öntudat alakításában mindig szerepet játszik, hogy a fejlődéshez milyen hálózatok, szereplök, akciók és szervezetek kötődnek és azok között milyen konszenzusok és konfliktusok lépnek fel. Azt már az elmúlt évek területfejlesztési politikái bizonyították, hogy a pénz, illetőleg a fejlesztési támogatások az egyik legföbb mozgatórugói a regionális együttmüködésnek és cselekvésnek. Azt is mondhatnánk, hogy a regionális öntudatnak alapvetően nem terekre, térkategóriákra vagy individuumokra kell vonatkoznia, hanem cselekvési helyzetekre, és mindenekelött kommunikációs rendszerekre. A regionális öntudatot nem pusztán, mint területi mintát lehet tanulmányozni, hanem mint a társadalmi kommunikáció vagy ideológiai rendszerek részét is.

Ami a hazai regionális politikát és a regionális identitás kibontakozását illeti, tulajdonképpen nem jutottunk lényegesen elöre az elmúlt évtizedben. Hiszen, ahol a regionális politikai célok formálódnak, ott régiókról beszélünk, azonban ahol az eszközök vannak, ott csak önkormányzatok, de legalábbis a közszféra szereplöi találhatók meg. Tudjuk, hogy a gazdasági szféra mozgósitása, érdekeltté tétele a regionális cselekvésben éppen ott a leggyengébb, ahol a fejlődésbeli elmaradottság a legeröteljesebb. Magyarországon a regionális gazdaság - a Központi és Nyugatmagyarországi régiót leszámítva - szinte alig érzékelhetö. A civil szféra, noha intézményesültségi fokát tekintve egyre látványosabban van jelen, a szervezetek elsöprő többsége lokális szinten múködik, s nem jellemző rájuk a regionális szerepvállalás. A kistérségi lépték az az első lépcsőfok, amelyet néhảny civil szerveződés 
már bevett, $\mathrm{s}$ ahonnan esetleg a cselekvési tér kitágítása várható. A támogató, szponzoráló gazdaság hiánya miatt azonban a civilek csekély erőforrásokat birtokolnak. A polgárok közösségének, a helyi lakosságnak a megszólitása hosszú ideje elmaradt. A kommunikáció stratégiája és technikája sem Magyarország uniós csatlakozásának elókészítésekor nem került kidolgozásra, sem azóta az uniós támogatási alapok megnyílásához kapcsolódóan. (Az Új Magyarország Fejlesztési Terv és Operatív Programjainak internetes webfelületen történő véleményezési lehetőségét nem tekintjük ilyennek.) A regionális fejlesztési politika egy szük politikai és szakmai elit játékterévé vált, melynek nyelvezetét nem csak az egyszerü állampolgár, de a gazdasági szférában elmélyült vállalkozó sem érti. E hiátust a sajtó sokszor avatatlan tudósításai, illetve a konfliktusokra koncentráló és azokat fölnagyító média nyilvánvalóan nem tudja ellensúlyozni.

\section{A regionális intézmények jelentösége}

Már régebb óta tudjuk, hogy „A régió képét és identitáskritériumait a lakosság körében közvetitő társadalmi és regionális intézmények fejlödése nagyon jelentős az érintett társadalom tagjai regionális öntudatának ủjratermelỏdése szempontjából. $\mathrm{Az}$ intézmények erösítik a régió lakosaiban a közösségi érzést és annak újratermelödési folyamatát." (Paasi 1989, 72-74) E vonatkozásban nem csak a formális intézményekröl van szó, hanem pl. olyan társadalmi folyamatról is, amelyben kialakul egy terület sajátos neve, valamint más szimbólumai. A régió intézményesülési folyamatában a kulminációs pont az a legitimációt biztosító lépés, amikor a régió elnyeri autonómiáját, előbb közigazgatási értelemben, majd alkotmányjogi szinten is. Ekkor a régió már a társadalom térbeli szerveződésének integráns részévé válik. A közigazgatási státusz rögzíti a regionális identitás területi határait, bár a regionális identitás szempontjából talán fontosabbak azok a társadalmi intézmények, amelyek az információkat közvetítik az adott területről. Egyértelmü, hogy a regionális identitás intenzitása függ a régiók adott államon belüli intézményesültségétől, illetve államszerkezeti minőségétől, amely a tapasztalatok szerint sokszínü lehet:

- tervezési-támogatáspolitikai régió

- közigazgatási régió

- autonóm régió

- állami minőséggel bíró régió (föderális államberendezkedés esetében).

A kulturális identitás nagy fokban hozzájárul az endogén erőforrások mobilizációjához. A területi identitás ugyanis sem légüres térben, sem pedig izolált személyiségekben nem tud fejlődni. Az emberek gondolkodására, cselekvésére, érzékelésére hatnak a tapasztalások, a szocializációs folyamat, és nem utolsó sorban az intézmények hozzák létre és mélyítik el az identitást. A belső ellentéteket legyőző regionális politikai perspektívára akkor van esély, ha egy ügyre vonatkozóan közös identifikálódást, vagy másképpen szólva konszenzusos érdekartikulációt tud a régió fel- 
mutatni. Tehát a politikával szembeni elvárás, hogy széles egyetértéssel és konkrétan döntsön és cselekedjen. Ez különösen igaz a regionális politikára.

Megfelelỏ jogi és eljárási keretek, s különösképpen bizonyos intézményesülés nélkül nincs regionális identitás. Ugyanis a hatékony fejlesztési politikához ki kell alakulnia a regionális politikai és gazdasági szereplökben, a civil szférában, ső́t a lakosságban is a bizalomnak a regionális politikát hordozó szimbólumok és szereplök iránt. Amíg általánosságban beszélünk régióról, addig az csak absztrakció. A régió fejlődését érintő döntéshozatali mechanizmusban való széles részvételi lehetőség biztosítása nélkül nem várható az identitás megerősödése. Területi identitás és felelösségérzet összekapcsolódása akkor lehetséges, ha a régióban élők számára biztosítjuk, hogy életterük alakításában és megváltoztatásában részt vegyenek. Hozzá kell még tenni, amennyiben a regionális politika nem a társadalom számára fontos problémákkal foglalkozik, komolytalanná és érdektelenné válik, szélső esetben látszatmegoldásokat fog produkálni, amitől az identitás képződése nem várható.

Jelenleg a regionális intézményrendszer múködése sajnálatos módon nem ebbe az irányba mutat. Ez abból fakad, hogy a regionális hatalmi elit inkább elválasztja magát környezetétöl, semmint, hogy integrálódna vele. A delegáció elvén felépülö regionális fejlesztési tanácsok a rájuk vonatkozó szabályozás következtében nem alkalmasak a regionális identitás kialakulásának segítésére, ugyanis müködési gyakorlatuk a nyilvánosság és a társadalmi kontroll szempontjából egy jó ideje aggályos. A tanácsülések ugyan nyilvánosak, azokon bármely állampolgár hallgatóként részt vehet, de a testületi munka a laikusok számára alig értelmezhető, az előterjesztések konkrét ismerete nélkül követhetetlen. Az üléseken keresztül nem ismerhetö meg a politikai grémiumok érdemi munkája (Somlyódyné Pfeil 2004).

Szorosan idetartozó kérdés, hogy létezik-e, artikulálódik-e olyan regionális érdek, amely alkalmas a vele való azonosulásra? Az intézményesítés problematikáját nálunk az is fokozza, hogy a regionális fejlesztési tanácsok kötelező törvényi megalapítása óta alig tapasztalható előrelépés ebbe az irányba. Noha ma már a megyei ügyektöl és érdektől elvileg független elnököt választhat a testület, nem kell valamelyik megyei közgyülési elnöknek e pozíciót betöltenie, a gyakorlatban kevés pozitív hatása mérhetỏ a törvénymódosításnak. Amikor ugyanis a kulisszák mögé pillantunk, kiderül, hogy egyik regionális tanácsunk elnöke egyidejüleg három „lovon ül”, mert e tisztén kívül úgyszintén a tanácsban képviseli az egyik minisztert, tehát a végrehajtó hatalom egyik ágazatának érdekeit, miközben lokális szinten a régió egyik községének polgármestere és kistérsége vezéralakja. Arra is érdemes kitérni, hogy az oktatási tárca tanácsbeli képviselöje egyébiránt Országgyủlési képviselö, ami a hatalmi ágak teljes keveredésének élményét adja számunkra, a politikai döntéshozás szintjeinek összemosásáról nem is beszélve. Hasonlóan szomorú, hogy számos települési, föként városi polgármester, akiktől régiójuk képviseletét várnánk, a kormányzat színeiben foglalnak helyet a regionális tanácsokban. Hogy ebböl az érdekkavalkádból miként lesz regionális érdekartikuláció, az közel sem világos. E regionális metszetböl tulajdonképpen már nincs is értelme feltenni a kérdést, hogy ki vagy mi a régió Magyarországon? Sajnos, az intézményi struktúrák 
kevéssé visznek közelebb a megoldáshoz, legfeljebb az állapítható meg, hogy a régió a regionális tervezés keretét, területi léptékét adja.

$\mathrm{Az}$ eddigi gondolatokat számba véve nyitott a kérdés, vajon Magyarországon vannak-e a területfejlesztési-statisztikai régiónak olyan jegyei, amelyek a regionális identitás kialakulásának bázisává válhatnak? Már 1998-ban folytak vizsgálatok a regionális identitás állapotára nézve. Az akkori megállapítások szerint a regionalizmus politikai marketingje rendkívül kezdetleges volt hazánkban. Zürzavar volt tapasztalható a régió határai, elnevezése, funkciója, sőt fogalma tekintetében is (Pálné Kovács 2001). Ma sincs ez másképp, a regionális elit, ha egyáltalán beszélhetünk ilyenröl, nem rendelkezik régióépitési stratégiával, a régió a területfejlesztési támogatások és leginkább az uniós források felszivásának technikája. A regionális identitásformáló jellemzök értékelése alapján nem túlzottan derủs a jelenlegi helyzetkép, mivel a régiónak:

- Területi (földrajzi) határa van - szimbolikus, történelmi, tájegységi, nyelvi, kulturális stb. tartalom nélkül.

- Neve van, de szinte alkalmatlan emocionális kötődések ébresztésére.

- Kijelölt és ezért identifikációra alkalmas központja nincs.

- Hatalmi (döntéshozó) szerve van - de nem hordoz és nem artikulál regionális érdekeket és értékeket, legitimációja gyenge.

- Regionális intézmények léteznek - új térstruktúráknak, regionális illetékességủ vagy léptékủ állami és gazdasági szervek folyamatos születésének vagyunk tanúi az állampolgárok és közösségeik érdemi bevonása nélkül.

- A partnerségi elvủ tervezés és cselekvés - formálisan létezik az EU elvárásainak teljesítése érdekében.

- Regionális gazdaság nincs vagy alig látható.

- Regionális közlekedésről, illetve közlekedési hálózatokról nem beszélhetünk, a régiók belső kohézióját erősíti ilyen típusú átfogó fejlesztési program nem indult.

$\mathrm{Az}$ országos politika, amely a potenciális régióközpontok leépítését, gyengitését tủzte ki célul, áttételesen a régiók gazdasági fejlődését és a regionális identitás megalapozását veszélyezteti, hiszen ha végigtekintjük azokat a faktorokat, amelyek a regionális azonosságtudat szempontjából szerepet játszanak, akkor a gyenge legitimációt birtokló regionális fejlesztési tanácsokon, valamint a statisztikai és területfejlesztési régiók törvényben megvont üres határain kívül alig találunk kapaszkodókat. Sajnos, az EU Strukturális Alapjára elfogadott regionális operatív programok még mindig jórészt maradékelvủek, az ágazati operatív programokból kiszorult tevékenységeket, illetve projekteket támogatnak.

\section{A regionalizáció pozitiv ellenpéldái}

A közigazgatás szférájában zajló regionalizálás és decentralizáció a városrégiók képződésére is hat, az együttmüködések új szervezeti formába öntése kiváló táptalaját szolgáltatja a regionális identitás fölépítésének. İgy a városi vonzáskörzeti reformok az önkormányzati berendezkedés alapjait érintő közjogi változásokat is 
elöidézhetnek, amikor például az intézményesített együttmüködés túllép a települési szint és az alsó középszint közötti szokásos feladat- és hatáskör-megosztáson és regionális léptékben értelmeződő feladatokat céloz. Tehát adott esetben $a$ regionalizáció egy válfaját is megtestesitheti.

Az agglomeráció nagy múltra visszatekintó településközi együttmüködésének alapjain valósult meg az „alulról jövő” regionalizáció egyedülálló példája Németország Alsó-Szászország tartományában. Noha az 1,1 millió lakost tömörítő hannoveri agglomeráció intézményesítési megoldása első megközelítésre közigazgatási karakterủnek látszik, egyértelmủ célja és mozgatórugója a térség gazdasági fejlődésének biztosítása volt a regionális és nemzetközi gazdasági térben. A cél elérésének kulcsfontosságú eszköze volt a térség fejlödésének garantálása az egységes tervezési tevékenységen keresztül, amit tovább erösített az idejekorán kiépített egységes nagytérségi közlekedési rendszer. A tartományi törvényhozó, amikor 1962-ben első ízben formalizálta a nagyvárosi tér együttmúködési kapcsolatait legalábbis ennek a várakozásának adott hangot (Kriegel 2000).

1996 óta élt az a javaslat, amely a hannoveri régió közigazgatási újrastrukturálását célozta. A nagytérség három hatalmi tényezője által megfogalmazott vitaanyag a hannoveri régió új típusú intézményesítése mellett tette le voksát, melyet a tartományi kormány támogatásában részesített. 1999-ben már megindult a törvényalkotási folyamat, melynek eredményeként az Alsó-szászországi parlament törvényt hozott a hannoveri régió, mint közvetlen választással létrejövö közjogi testület alapításáról. A 2001 szeptemberében megtartott választások a mintegy hat éves elökészítỏ procedúra betetőzéseként életre hívták a regionális gyülést. A regionalizálási koncepció lényege, hogy mind a hannoveri járást, mind az önkormányzati céltársulást feloszlatták, míg Hannover városa elveszítette járási jogállását, annak érdekében, hogy az ún. „regionális járás”, mint valamennyi szervezet jogutódja megszülessék (KleineSellnow, L.-Sellnow, R. 1999). A reform hátterében több igazgatási kérdés várt megoldásra, mint például az, hogy miként tagolható a közigazgatás olyan szintekbe, amelyek nagyobb polgárközelséget tudnak biztosítani a korábbi állapotnál?

A közigazgatási reform képébe bújtatott régióalapítás három célt fogalmazott meg, a hatékony, a szolidáris és a polgárközeli régió jövőképét. Ezek közül a szolidáris régió célkitüzése a feladatok szintek közötti ủjraelosztásán keresztül a közigazgatást közelebb vitte a lakossághoz. Figyelemre méltó, hogy a reformelképzelések intenzív vitán mentek keresztül mind a politika, mind az igazgatás berkeiben, sőt az 1998-as év folyamán több fórum keretében a polgárok véleményének becsatornázása is megtörtént tematikusan, szociálisan és társadalmilag érintett szervezeteken, csoportokon keresztül. Az érdekviszonyok megfelelö kiegyensúlyozása érdekében arányos képviseletet kaptak az agglomeráció külső és belső körgyưrüuét alkotó települések, valamint a városközpont különböző városrészeinek meghívottai. Négy workshopot szerveztek az állampolgárok számára, mert a döntéshozók fontosnak vélték a regionális reform közösségi kontrollját. Emellett megvalósíthatósági tanulmány készült a hatások számbavételére és a finanszírozási javaslatokra vonatkozóan. 
A reform egészének értéke a két irányban végrehajtott decentralizációval mérhetö. Dicséretes az a szándék, amely egyfelől a területi államigazgatás egyes funkcióit áldozta fel a régió intézményének oltárán. Másfelől a járási szint kiiktatása a közigazgatás rendszeréből lokális szinten ugyancsak decentralizációt eredményezett azáltal, hogy az integrált települési önkormányzatokat tette (pl. építéshatósági hatáskörök, oktatás, közlekedési hivatal stb.) a felszámolt hannoveri járás regionalizálás után még fennmaradó feladatköreinek hordozóivá. Az agglomerációt alkotó önkormányzatok természetesen megtartották jogi önállóságukat (Kleine-Sellnow, L.-Sellnow, R. 1999, 438).

Figyelemre méltó, hogy a Hannoveri Nagytérségi Önkormányzati Szövetség (Kommunalverband Großraum Hannover), mely önkormányzati céltársulás formájában mintegy 35 évig állt fenn, intézményi bázisát alkotta a hannoveri régiónak. Mert egyébként közigazgatási régió, más néven a regionális járás gondolata meglehetősen régóta élt a német jogi irodalomban, elöször 1965-ben mérlegelték ennek az intézménynek a bevezethetőségét több német tartományban. Az eredeti modell olyan önkormányzati képviselö-testülettel számolt, amely egyidejüleg államigazgatási kerületként is funkcionált volna, és vagy a járás vagy a kormánykerület, mint közigazgatási szint beolvadását feltételezte volna. A történelem során mind a CDU (1965), mind az SPD (1968) részéröl volt példa arra, hogy a hesseni, illetőleg a schleswig-holsteini tartományi parlamentben olyan törvénytervezetet nyújtottak be, amely a régió bevezetését javasolta adott tartományban. Ezek az elképzelések azonban hosszú időn keresztül kudarcot vallottak, mígnem helyi és területi szereplök együttes kezdeményezésére tartományi szintủ döntés született a hannoveri regionális járás intézményesítéséröl.

Egy másik jó példaként szolgál az ugyancsak hosszú szerves fejlődés eredményeként, regionális léptékủ intézményként 1994-ben létrehozott Stuttgarti Régiószövetség. Megalakulásakor közvetlenül választott régiógyülésével saját politikai szervet kapott. A szervezet alapításának célja az volt, hogy a nagyvárosi vonzáskörzetet, mint régiót a telephelyek európai versenyében előkelő helyhez juttassa. Az agglomeráció lakosságának igénye mutatkozott egy politikai jellegủ megoldásra, amit a regionális menedzsment segítségével sikerült megvalósítani.

A régiószövetségnek három szerve van, a régiógyủlés, a szövetség elnöke és a regionális igazgató. A régiógyülésbe a választópolgárok általános, közvetlen, szabad, egyenlő és titkos szavazás útján 80 tagot választanak, ahol is a választási területet a régió területe jelenti. A jelölés választókörzetenkénti listákon történik, a választókörzeteket pedig a szövetséget alapító járások alkotják. A jelöltek irányában fontos megkötés - ami a regionális identitás erősítésével hozható összefüggésbe -, hogy választókörzetük valamely községében választójoggal kell rendelkezniük, tehát helyi illetőségünek kell lenniük. A választójogosultságot is szabályozza a törvény. $\mathrm{Az}$ általános választásokhoz képest többletkövetelményként szerepel, hogy a választópolgár egyetlen lakóhelyének, vagy több lakása közül a fö lakhelyének legalább három hónapja a régió területén kell lennie. Pozitív diszkrimináció érvényesül azokkal az elköltözöttekkel szemben, akik, ha elköltözésüktől számított három éven belül térnek vissza, akkor türelmi idő nélkül azonnal visszakapják elveszített válasz- 
tójogukat. A szabályozás szerint az aktív és passzív választójog egybeesik. Mindezeknek a szabályoknak, illetve intézményeknek az eredményeként könyvelhető el, hogy a régiógyülésben folyó munka segitett életre hívni egy történelmileg korábban nem létezett régióban a regionális identitást, s a szövetség köré társadalmi és önkormányzati kezdeményezések sora csoportosult.

A példákkal mindössze arra szerettünk volna rávilágítani, hogy a regionális identitás formálása tudatos politikát igényel. Hosszú szisztematikus építkezés, az intézményesítés különböző fázisai és a lakosság, valamint a helyi közösségek bevonásával folytatott kommunikáció elözik meg az erös politikai legitimitással rendelkezö régiók létrejöttét. A két példa egyúttal a normatív régió kialakitását igyekezett érzékeltetni, ahol is a területi határok megvonása nem csupán új térkategóriát, hanem regionális közigazgatási egységet is eredményezett. Azt már csak zárójelben teszszük hozzá, hogy politikai konszenzusra és nagyfokú bizalomra van szükség ahhoz, hogy egy ilyen léptékủ regionális reform célba érjen.

\section{Zárszó}

Az eddigiekben vázoltakat akként sommázhatnánk, hogy valamely régióval történő identifikációnak akkor lehet esélye, ha az egyének és a régió közössége számára megadatik az életviszonyok regionális alakításának felelössége, mely másként nem képzelhetỏ el, minthogy a régió egyfajta autonómiához jut, amelynek legalább a szubnacionális szintre telepített döntési kompetenciákban és pénzügyi eszközökben kell kifejeződnie. Ez azonban az éremnek csupán az egyik oldala. Söt ezek a tényezők absztrakciók maradnak mindaddig, amíg csak beszélünk a régióról. Ezért az identitás-koncepció elengedhetetlen része a régió lakosságának széles körủ részvételi lehetősége a döntéshozási folyamatban. Már rég „lerágott csont”, hogy az identitás és felelősségérzet az épített és természeti környezet iránt csak akkor alakul ki, ha a helyben élő embereknek alakítási, módosítási, ráhatási lehetőségük van. Vagyis, ha egyének és közösségek a maguk és a régió sajátosságait ki tudják bontakoztatni (Danielzyk-Wiegandt 1987). Ily módon a régió a demokrácia elemtöl, a nyitott diskurzustól elválaszthatatlan, máskülönben sem a regionális politikai kultúra kialakulásának, sem a gazdasági döntési struktúrák létrejöttének nem lesz esélye.

Hazánkban a regionalizáció égisze alatt zajlott eddigi folyamatokról az a benyomásunk, hogy noha a megalkotott jogszabályoknak, a végrehajtott intézményi átszervezéseknek a végső célja az állampolgárok életkörülményeinek a jobbítása kell, hogy legyen, a humán elem végig figyelmen kívül maradt. A lakosságnak nincs ismerete, tudása az új struktúrákról, azoknak életterét átalakító karakteréről, miből is táplálkozna az ahhoz való kötődés kialakulása, nem is beszélve egy új térbeli identitás kialakulásáról. Tegyük hozzá, nem lenne nélkülözhetỏ az intézményesítéshez a jogalkotás előzetes hatásvizsgálatát sem lefolytatni.

Az, amirôl az utóbbi néhány év kormányzati politikája szól, a kisebb és hatékonyabb állam bevezetése, biztosan nem elegendỏ ahhoz, hogy a társadalmat meg- 
nyerjük a regionalizáció számára. A cél akkor lehet szalonképes, ha a lakosság életfeltételeinek és a gazdaság környezetének javulását is ígéri, mégpedig az esélyegyenlőség bázisán. Az utóbbi tényező nélkül nehezen képzelhető el a reformmal történő identifikáció. E szempontok figyelmen kívül hagyásával is végrehajtható például az államigazgatás regionalizációja, de teljesen felesleges. És elsősorban nem azért, mert az Alkotmánybíróság ítéletében megállapította alkotmányellenességét, hanem, mert nem lehet a társadalom és hatalom térbeli szerkezetének átalakítását csak köztisztviselői létszámokra és politikai zsákmányszerzésre alapozva végrehajtani. Profán érvnek túnik, de az állampolgár nem érzéketlen arra, hány kilométert kell utaznia a szomszéd megye székhelyére ügyet intézni, miközben a feladatok és hatáskörök áthelyezésének közlekedési, anyagi stb. vonzataival az állam nem vetett számot. A lakosság számára máris drágább lett a közigazgatás, de mit kapott cserébe, milyen előny társul, illetve társult volna a regionalizációhoz? Kérdésünket egyáltalán nem tekintjük költőinek.

$$
\text { Jegyzet }
$$

${ }^{1}$ Jelen tanulmány egyes részletei elhangzottak a Politológus Vándorgyủlés 2007. c. konferencián a IV. Civil, helyi és regionális identitások blokkban, korreferátum formájában. PTE BTK Pécs. 2007, június 22-23.

\section{Irodalom}

Berényi I. (2003) Közép-Európa kulturális régióinak kérdése. - Ábrahám B.-Gereben F.-Stekovics R. (szerk.) Nemzeti és regionális identitás Közép-Európában. Pázmány Péter Katolikus Egyetem Bölcsészettudományi Kar, Piliscsaba. 17-26. o.

Blotevogel, H.H.-Heinritz, G.-Popp, H. (1987) Regionalbewußtsein - Überlegungen zu einer geographischlandeskundlichen Forschungsinitiative.-Informationen zur Raumentwicklung. 7/8. 409-418. o.

Danielzyk, R.-Wiegandt, C-Ch. (1987) Regionales Alltagsbewußtsein als Faktor der Regionalentwicklung? -Informationen zur Raumentwicklung. 7/8. 441-450. o.

Horváth Gy. (2007) Régióközpontok Európában. - Magyar Tudomány. 6. 704-720. o.

Kleine, W.-Sellnow, L.- Sellnow, R. (1999) Die Regionalreform der Region Hannover aus Sicht der Bürger. Ein Experiment der Bürgerbeteiligung. - Raumforschung und Raumordnung. 5-6. 437-441. o.

Kriegel, J. (2000) Gemeindeübergreifende Zusammenarbeit im Kommunalverband Großraum Hannover. Jähnke, P.-Gawron, T. (Herg.) Regionale Kooperation - Notwendigkeit und Herausforderung kommunaler Politik. Institut für Regionalentwicklung und Strukturplanung, Erkner bei Berlin. 77-88. o.

Kruse, H. (1990) Reform durch Regionalisierung. Eine politische Antwort auf die Umstrukturierung der Wirtschaft. Campus, Frankfurt/Main-New York.

Kühn, M. (2001) Regionalisierung der Städte. - Raumforschung und Raumordnung. 5-6. 402-411. o.

Meier-Dallach, H.-P. (1980) Räumliche Identität - Regionalistische Bewegung und Politik. Informationen zur Raumentwicklung. 5. 301-313. o.

Oláh M. (2000) Adalékok a regionális identitás megrajzolásához. - Glatz F. (szerk.) Területfejlesztés és közigazgatás-szervezés (Megve, régió, kistérség). Magyarország az ezredfordulón. Stratégiai kutatások a Magyar Tudományos Akadémián. Magyar Tudományos Akadémia, Budapest. 143-182. o.

Paasi, A. (1989) A régiók fejlödése és a regionális identitás kialakulása. - Tér és Társadalom. 3. 70-79. o.

Pálné Kovács I. (2001) Käzigazgatás és regionális politika. Dialóg Campus, Budapest-Pécs.

Somlyódyné Pfeil E. (2004) A gazdaságfejlesztés megjelenési formái a területfejlesztési régiók szintjén. - Pálné Kovács I. (szerk.) Versenyképesség és igazgatás. MTA Regionális Kutatások Központja, Pécs. 141-160. o.

Soós E. (2001) Az europanizáció hatása a regionális identitás fejlődésére. - Karikó S. (szerk.) Európaiság. Politikai és morális kultúra. Áron Kiadó, Budapest. 95-104. o. 
Szijártó Zs. (2002) Turizmus és regionalizmus a Káli-medencében. Egy kutatás tapasztalatai. - Fejōs Z.Szijårtó Zs. (szerk.) Egy tér alakváltozásai. Tabula könyvek 4. Néprajzi Múzeum, Budapest. 7-21. o.

Szörényiné Kukorelli I. (2000) Régió-e a Nyugat-Dunántúl? - Glatz F. (szerk.) Területfejlesztés és közigazgatás-szervezés (Megye, régió, kistérség). Magyarország az ezredfordulón. Stratégiai kutatások a Magyar Tudományos Akadémián. Magyar Tudományos Akadémia, Budapest. 209-230. o.

Wiechmann, Th. (2000) „Die Region ist tot - lebe die Region!” Anmerkungen zur Diskurskonjunktur und Relativierung des Begriffes. - Raumforschung und Raumordnung. 2-3. 173-184. o.

\section{ASPECTS OF THE INTERPRETATION OF THE REGIONAL IDENTITY}

\section{EDIT PFEIL SOMLYÓDYNÉ}

How to create regional identity? What role do the space and the culture play in this process? Can we classify the special characteristics of regional identity compared to spatial identity? The concept is rather new, similar to the concept of the regionalization of the regions.

The development and spatial planning regions established ten years ago, haven't got any historical tradition or geographical borders in Hungary. So the article is to look into the factors how to strengthen regional identity. The instruments of the participatory democracy, the communication, the designation of the regional centres, and not least the foundation of new regional intstitutions can contribute so the creation of regional identity within the population. On the basis of the experiencies other countries, these latter are important, ones to give the framework of common activities within the new regional boundaries. 